\title{
Analisa Pengaruh Gaya Kepemimpinan Terhadap Kinerja Pegawai Pada PD Pasar Jaya Hwi Lindeteves Jakarta Barat
}

\author{
Nurvi Oktiani \\ Manajemen, Fakultas Ekonomi dan Bisnis, Universitas Bina Sarana Informatika \\ nurvi.nvk@bsi.ac.id
}

\begin{abstract}
Abstrak
Dalam suatu organisasi perlu adanya perencanaan yang matang terutama pada proses level manajemen, dimana dalam mendapatkan orang yang tepat dan posisi yang tepat merupakan isu dan peran serta tugas yang penting bagi seorang leader atau pemimpin, adapun tujuan dalam penelitian ini adalah menentukan pengaruh gaya kepemimpinan terhadap kinerja karyawan pada perusahaan dagang(PD) Pasar Jaya HWI Lindeteves Jakarta Barat pada bagian perawatan, teknik rancangan penelitian menggunakan kuantitatif, data diperoleh dengan menyebarkan kuesioner dengan sampel 36 responden Purposive sampling, teknika analisa data menggunakan uji koefien korelasi, determinasi, dan persamaan regresi, dari hasil diperoleh bahwa terdapat pengaruh antara gaya kepemimpinan dan kinerja karyawan, kedepannya perlu adanya peningkatan peran serta kepemimpinan dalam upaya peningkatan kinerja karyawan
\end{abstract}

Kata Kunci: kepemimpinan, kinerja, pegawai

\section{Analysis of the Influence of Leadership Style on Employee Performance at Pasar Jaya Trading Company Hwi Lindeteves, West Jakarta}

\begin{abstract}
In organization must have done planning in human resource management processing to get right person for the right position. the targets of human resource management in organization management functions tell about leadership issues. The purpose of the research to determine the influence of leadership style on employee performance in PD Pasar Jaya HWI Lindeteves West Jakarta in Nursing Field. The method is used the method of quantitative analysis. The data obtained through the spread of questionnaires with Likert scale measurements, for the sample of 36 respondents from a population of 40 employees. The technique analysis is used correlation coefficient test, coefficient of determination test, and test of regression equation. Based on the calculation of correlation coefficient obtained value of 0.385 indicates that the low level of relationship between leadership styles on employee performance, the coefficient of determination shows the value indicates that the influence of leadership style on employee performance influential and the rest influenced by others factors such as work discipline, motivation, training, job satisfaction and compensation. From the regression is meaning the leadership style plus 1 unit then will increase employee performance, For advice, the organization should has to head of the nursing field continue to work, improve and understand the application of leadership style to employees it can be more conducive.
\end{abstract}

Keywords: leadership, performance, employee

\section{PENDAHULUAN}

Leadership atau yang lebih dikenal dengan istilah kepemimpinan merupakan suatu proses pengaruh social yang mana memberikan pengaruh dalam mencari cara ataupun strategi yang mana melibatkan seluruh subordinat (pengikut dan bawahan) dan seorang pemimpin dapat diartikan sebagai seorang pemimpin dapat didefinisikan sebagai seorang yang mendelegasikan atau memberikan pengaruh satu sama lain dan bertindak sesuai dengan tujuan yang spesifik., karena pada masa sekarang ini organisasi membutuhkan seorang 
pemimpin yang mengarahkan kepada keefektifan organisasi dan mengetahui mengenai kompleksitas dan perubahan lingkungan yang sangat cepat (T.S, Nanjundeswaras wamy dan D.R Swami, 2014:57)

Leadership merupakan semacam kekuatan yang mana dapat diartikan seseorang yang memiliki suatu kemampuan untuk mempengaruhi ataupun merubah suatu nilai, kepercayaan, tingkah laku dan kepribadian orang lain (Hao, Moo Jun dan Yazdanifard, 2015), seorang pemimpin yang memiliki kekuatan dalam pola kepemimpinan akan menjadi suatu contoh atau puanutan yang baik (role model) terhadap keryawan, karena seorang pemimpin yang memiliki kemampuan mencapai suatu tujuan dengan cara efektif, akan menerima akan memperoleh suatu hasil yang terbaik dari pencapaiannya, dan akan mendapat pengakuan dari subordinate atau atau dari karyawan. Lebih daripada hal tersebut (Visser, 2013)

Proses kegiatan suatu organisasi suatu perusahaan pasti akan mengalami hambatan dan rintangan dalam mencapai tujuannya. Salah satunya adalah upaya dalam peningkatan sumber daya manusia dalam perusahaan atau organisasi. Banyak yang telah mengalami kemunduran bahkan kegagalan dalam mencapai tujuannya hanya karena permasalahan peningkatan sumber daya manusia.

Pola hubungan yang terjadi antara atasan dengan bawahan dapat menyebabkan pegawai merasa senang atau tidak senang bekerja di perusahaan tersebut, untuk itulah dalam organisasi selalu dilakukan perencanaan pengolahan sumber daya manusia untuk mendapatkan orang yang tepat untuk jabatan yang tepat. Salah satu sasaran pengolahan sumber daya manusia pada fungsi manajemen organisasi adalah menyangkut masalah kepemimpinan, seseorang yang ditunjuk sebagai pemimpin maupun yang diakui oleh anggota sebagai orang yang pantas memimpin mereka, dialah yang menjalankan fungsi organisasi tersebut. Cara dan pola tingkah laku pemimpin diartikan oleh bawahan yang berkerjasama dengannya sebagai gaya kepemimpinan. Kepemimpinan adalah kemampuan untuk mempengaruhi anggota atau kelompok untuk bersedia melakukan kegiatan demi mencapai suatu tujuan.

Seorang pemimpin dalam organisasi harus dapat menciptakan integrasi yang serasi dengan para bawahannya juga termasuk dalam membina kerja sama, mengarah dan mendorong gairah kerja para bawahan sehingga tercipta motivasi positif yang akan menimbulkan niat dan usaha (kinerja) yang maksimal, juga didukung oleh fasilitas-fasilitas organisasi untuk mencapai sasaran organisasi. Dimana seorang pemimpin sebagai salah satu bagian dari manajemen memainkan peran yang penting dalam mempengaruhi dan memberikan sikap serta perilaku dan kelompok, sehingga membentuk gaya kepemimpinan yang pemimpin terapkan.

Dapat dipastikan bahwa perilaku seorang pemimpin adalah pengaruh yang akan menimbulkan pemahaman tersendiri yang akan berpengaruh terhadap kondisi psikologis bawahan, ada bawahan yang melihat, mengamati dan meniru perilaku pemimpin yang ditampilkan atasan dirasakan sebagai sesuatu yang diharapkan bawahan maka akan memiliki dampak yang lebih baik terhadap kinerja pegawai, sebaliknya apabila perilaku kepemimpinan yang ditampilkan atasan sebagai sesuatu yang tidak sesuai dengan harapannya maka akan berpengaruh kurang baik terhadap kinerja pegawai.

Oleh karena itu untuk meningkatkan kembali kinerja pegawai tersebut, maka salah satu faktor yang perlu diperhatikan adalah menyangkut gaya kepemimpinan yang diterapkan oleh pemimpin-pemimpin pada perusahaan yaitu bagaimana agar gaya kepemimpinan yang diterapkan para pemimpin dapat menunjang kinerja pegawainya agar lebih baik. Informasi mengenai gaya kepemimpinan ini penting diketahui oleh pihak perusahaan sendiri karena gaya kepemimpinan merupakan salah satu komponen penting yang akan mempengaruhi kinerja organisasi.

Peningkatan kinerja karyawan juga akan membawa kemajuan bagi perusahaan untuk dapat bertahan dalam suatu persaingan lingkungan bisnis yang tidak stabil. Oleh karena itu upaya-upaya untuk meningkatkan kinerja karyawan merupakan tantangan managemen yang paling serius karena keberhasilan untuk mencapai tujuan dan kelangsungan hidup perusahaan tergantung pada kualitas kinerja sumber daya manusia yang ada didalamnya. Kinerja karyawan yang tinggi sangatlah diharapkan oleh perusahaan tersebut. Semakin banyak karyawan yang mempunyai kinerja tinggi, maka produktivitas perusahaan secara keseluruhan akan meningkat sehingga perusahaan akan dapat bertahan dalam persaingan global. Karyawan dituntut untuk mampu menyelesaikan tugas dan tanggung jawabnya secara efektif dan efisien. Keberhasilan karyawan dapat diukur melalui kepuasan konsumen, berkurangnya jumlah keluhan dan tercapainya target yang optimal, berdasarkan latar belakang diatas dapat dsimpulkan bahwa gaya kepimpinan merupakan faktor yang sangat signifikan dan krusial penerapannya bagi perusahaan, dan adapun tujuan penelitian ini adalah untuk melihat sejauh mana pengaruh gaya kepemimpinan terhadap peningkatan kinerja karyawan. 


\section{TINJAUAN PUSTAKA}

\subsection{Gaya Kepemimpinan}

Menurut (tampi dan Johannes, 2014:3) dimana Gaya kepemimpinan adalah pola tingkah laku yang telah dirancang untuk dapat memaksimalkan kinerja yang dimiliki oleh bawahannya sehingga tercapainya tujuan organisasi melalui peningkatan kinerja organisasi yang maksimal sedangkan (Anwar dan Ruyatnasih. 2013:110) memberi pengertian bahwa gaya kepemimpinan merupakan seni dalam mempengaruhi perilaku bawahan sehingga mereka mau bekerja sama secara produktif dalam upaya mencapai tujuan perusahan atau organisasi, pengertian gaya kepemimpinan lainnya diungkapkan oleh Mulyadi (2011) dimana dalam pengertian ini gaya kepemimpinan merupakan sekumpulan ciri ataupun karakteristik dalam upaya pencapaian sasaran guna untuk mempengaruhi bawahan yang melibatkan pola peilaku dan strategi yang disukai dan sering diterapkan oleh seorang pemimpin

Menurut kartono (2010) gaya kepemimpinan dapat diuraikan sebagai berikut:

1. Gaya kepemimpinan adalah perilaku, karakteristik dan atau tindakan pemimpin dalam upaya mempengaruhi para anggota atau karyawan

2. Gaya kepemimpinan adalah perilaku atau tindakan pemimpin dalam melaksanakan tugas-tugas yang mencangkup kegiatan manajerial

Rivai (2010) menyatakan bahwa gaya kepemimpinan merupakan perilaku dan strategi yang merupakan hasil kombinasi dari filsafah, keterampilan ataupun keterampilan, sifat dan karakteristik, yang diterapkan seorang pemimpin ataupun leader ketika dalam usaha mempengaruhi kinerja bawahannya".

Berdasarkan tujuan diatas kita dapat mengambil kesimpulan bahwa kepemimpinan merupakan suatu cara, perilaku serta strategi yang dapat diambil dari kombinasi keterampilan serta keahlian dan karakteristik dalam upaya mempengaruhi karyawan ataupun bawahannya agar tercapainya tujuan organisasi

\section{Unsur-unsur Kepemimpinan}

Unsur-unsur yang dibangun dalam kepemimpinan menurut Bangun (2012), terbagi menjadi empat unsur, yaitu:

1. Kumpulan Orang : sekumpulan orang disini dapat diartikan sebagai orang yang menerima arahan dan perintah dari pimpinan

2. Kekuasaan : kekuatan yang mana diisyaratkan bagi seorang peyang dimiliki seorang pemimpin untuk mempengaruhi para pengikutnya dalam melaksanakan tugasnya.

3. Pengaruh : dimana kemampuan untuk mempengaruhi para anggota organisasi sehingga dapat mempengaruhi tugasnya

4. Nilai : kemampuan untuk menggunakan tiga unsur sebelumnya dan mengakui bahwa kemampuan bawahan berkaitan dengan nilai.

\section{Fungsi Kepemimpinan}

Dalam maknanya fungsi kepemimpinan merupakan fungsi yang melekat pada seorang pemimpinan sehingga dapat dilihat dengan adapun tujuannya agar tercapainya yang kegunaan. (Rivai,et al., 2011) menyatakan bahwa: fungsi kepemimpian dapat diartikan sebagai proses memandu, menuntun, membimbing, membangun, memberi, atau membangunkan motivasi-motivasi kerja, mengemudikan organisasi, serta menjalin jaringan-jaringan komunikasi yang baik sehingga dapat memberikan sipervisi/pengawasan yang efesien dan efektif, serta membawa pengikutnya kepada sasaran yang ingin dituju, sesuai dengan ketentuan waktu dan perencanaan.

Menurut (Rivai, et al, 2011:34), memberikan fungsi kepemimpinan secara operasional yang dibedakan dalam lima fungsi pokok kepemimpinan, yaitu:

1. Fungsi instruksi

Fungsi ini bersifat komunikasi satu arah, dimana pemimpin sebagai komunikator merupakan pihak yang menentukan apa, bagaimana, dan dimana perintah itu dikerjakan agar setiap keputusan dapat dilaksanakan secara efektif dan efesien. Kepemimpinan yang efektif dan efisien sangat diperlukan kemampuannya untuk menggerakkan dan memotivasi orang lain agar mau melakukan perintah serta keputusan yang telah diambil.

2. Fungsi konsultasi

Fungsi ini bersifat komunikasi antar dua arah, dimana pada tahap pertama dalam usaha menetapkan suatu keputusan, pemimpin sering kali memerlukan bahan pertimbangan yang mengharuskannya berkonsultasi dengan orang-orang yang dipimpinnya agar dinilai mempunyai berbagai bahan informasi yang diperlukan dalam menetapkan keputusan. Sedangkan tahap berikutnya konsultasi dari pemimpin pada orang-orang 
yang dipimpin dapat dilakukan setelah keputusan ditetapkan dan sedang dalam pelaksanaan. Konsultasi itu dimaksudkan untuk memperoleh masukan serta umpan balik (feedback) dalam rangka memperbaiki dan menyempurnakan keputusan-keputusan yang telah ditetapkan dan dilaksanakan. Dengan menjalankan fungsi konsultatif yang telah ditetapkan dan dilaksanakan, dimana dengan menjalankan fungsi konsultatif dapat diharapkan keputusan-keputusan pemimpin akan mendapatkan dukungan dan lebih mudah menginstruksikannya, sehingga kepemimpinan berlangsung efektif.

3. Fungsi pastisipasi

Dalam menjalankan fungsi partisipatif ini pemimpin berusaha selalu mengaktifkan orang-orang yang dipimpinnya, baik dalam keikutsertaan mengambil keputusan maupun dalam proses pelaksanaanya. Partisipasi disini tidak berarti bebas berbuat semaunya. Tetapi dilakukan secara pengendalian dan pengarahan berupa kerjasama dengan tidak mencampuri atau mengambil tugas pokok karyawan lain. Keikutsertaan pemimpin harus tetap dalam fungsi sebagai pemimpin dan bukan pelaksanaan.

4. Fungsi Delegasi

Fungsi ini dilaksanakan dengan memberikan pelimpahan wewenang serta membuat adan atau menetapkan keputusan, baik melalui persetujuan maupun tanpa persetujuan dari pimpinan. Fungsi delegasi pada dasarnya berarti kepercayaan. Orang-orang penerima delegasi itu harus diyakini merupakan pembantu pemimpin yang memiliki kesamaan prinsip, persepsi, serta aspirasi.

5. Fungsi pengendalian

Fungsi pengendalian bermaksud bahwa kepemimpinan yang sukses atau efektif mampu mengatur aktivitas anggotanya secara terarah dan dalam koordinasi yang efektif sehingga memungkinkan tercapainya tujuan bersama secara maksimal. Fungsi pengendalian dapat diwujudkan melalui kegiatan bimbingan, pengarahan, koordinasi, dan pengawasan.

\section{Macam-macam Gaya Kepemimpinan}

Sutrisno (2013), mengajukan enam kinerja yang dapat digunakan untuk mengukur kinerja, yaitu:

1. Quality, merupakan tingkat sejauh mana proses atau hasil pelaksanaan kegiatan mendekati kesempurnaan atau mendekati tujuan yang diharapkan.

2. Quantity, merupakan jumlah yang dihasilkan, misalnya jumlah rupiah, unit, dan siklus kegiatan yang dilakukan

3. Timeliness, merupakan sejauh mana suatu kegiatan diselesaikan pada waktu yang dikehendaki, dengan memerhatikan koordinasi output lain serta waktu yang tersedia untuk kegiatan orang lain.

4. Cost effectiveness, merupakan tingkat sejauh mana penggunaan sumber daya organisasi (manusia, keuangan, teknologi, dan material) dimaksimalkan untuk mencapai hasil tertinggi atau pengurungan kerugian dari setiap unit penggunaan sumber daya.

5. Need for supervision, merupakan tingkat sejauh mana seorang pekerja dapat melakukan suatu fungsi pekerjaan tanpa memerlukan pengawasan seorang supervisor untuk mencegah tindakan yang kurang diinginkan.

6. Interpersonal impact, merupakan tingkat sejauh mana karyawan memelihara harga diri, nama baik, dan kerjasama di antara rekan kerja dan bawahan.

\section{Penelitian}

\section{Pengaruh antara Gaya kepemimpinan dan Kinerja}

Penelitian pendahuluan yang telah dilakukan oleh Fahmi (2013) dimana didapatkan hasil pengaruh gaya kepemimpinan terhadap kinerja jika seorang pemimpin harus mampu mengarahkan bawahannya untuk memiliki kompetensi dalam bekerja. Karena dalam kepemilikan kompetensi pegawai tersebut akan mampu mendorong peningkatan kualitas kerja yang mereka hasilkan. Untuk itu, setiap pemimpin bukan hanya dituntut untuk mampu bekerja secara maksimal namun juga mengerti dimana permasalahkan dalam mengembangkan bakat yang dimiliki oleh seorang pegawai.

\section{METODE PENELITIAN}

Rancangan dalam penelitian menggunakan rangan kuantitatif, adapun populasi dan sampel penelitian adalah karyawan pada perusahaan daerah Pasar Jaya HWI Lindeteves Jakarta barat dan sampel berjumlah 36 pegawai, teknik pengambilan sampel dengan menggunakan teknik Purposive Sampling pada Non-probability Sampling, teknik pengumpulan data dengan melakukan penyebaran kuesioner serta observasi lapangan, teknik analisa data menggunakan regresi linear sederhana dengan melakukan pengujian diantaranya uji reliabilitas, uji validitas, uji koefisien determinasi, dan uji persamaan regresi linear 


\section{HASIL DAN PEMBAHASAN}

\section{Uji Instrumen Penelitian}

Berdasarkan hasil pengolahan data maka diperoleh hasil sebagai berikut:

1. Uji Validitas

Pengujian ini dilakukan dengan membandingkan $r$ hitung dengan $r$ tabel. Nilai $r$ hitung merupakan hasil korelasi jawaban responden pada masing-masing pernyataan di setiap variabel yang di analisis dengan program SPSS. Besarnya $\mathrm{r}$ tabel dengan taraf signifikansi 5\% adalah 0,329. Dengan ini variabel $\mathrm{X}$ yang terdiri dari 12 pernyataan tersebut telah teruji valid dan variabel Y yang terdiri dari 12 pernyataan dinyatakan valid. Hasil validitas melalui program SPSS dapat dilihat pada lampiran dan berikut adalah tabel rangkumannya:

Tabel .1. Hasil Validitas

\begin{tabular}{|c|c|c|c|c|}
\hline Variabel & Indikator & $\begin{array}{l}\mathbf{r} \\
\text { hitung }\end{array}$ & $\begin{array}{l}r \\
\text { tabel }\end{array}$ & Keterangan \\
\hline $\begin{array}{l}\text { Gaya } \\
\text { Kepemimpinan } \\
\text { (X) }\end{array}$ & $\begin{array}{l}\text { Pengerak } \\
\text { Motivasi } \\
\text { Pembuat keputusan } \\
\text { Pertimbangan } \\
\text { Umpan balik (Feedback) } \\
\text { Dukungan } \\
\text { Aktif dan Inovatif } \\
\text { Pengendalian dan pengarahan } \\
\text { Kepercayaan } \\
\text { Kewenangan tugas } \\
\text { Pengaturan aktivitas } \\
\text { Pembimbingan }\end{array}$ & $\begin{array}{l}0,764 \\
0,689 \\
0,814 \\
0,796 \\
0,780 \\
0,724 \\
0,861 \\
0,755 \\
0,848 \\
0,838 \\
0,770 \\
0,736\end{array}$ & 0,329 & $\begin{array}{l}\text { Valid } \\
\text { Valid } \\
\text { Valid } \\
\text { Valid } \\
\text { Valid } \\
\text { Valid } \\
\text { Valid } \\
\text { Valid } \\
\text { Valid } \\
\text { Valid } \\
\text { Valid } \\
\text { Valid }\end{array}$ \\
\hline $\begin{array}{l}\text { Kinerja } \\
\text { Pegawai (Y) }\end{array}$ & $\begin{array}{l}\text { Pemprosesan } \\
\text { Hasil atau output } \\
\text { Kualitas pekerjaan } \\
\text { Siklus kegiatan } \\
\text { Ketepatan waktu } \\
\text { Koordinasi dan pengaturan waktu } \\
\text { Pemamfaatan sumber daya } \\
\text { Minimalisir resiko } \\
\text { Pelaksanaan tugas } \\
\text { Pengawasan dan evaluasi } \\
\text { Kepercayaan diri } \\
\text { Hubungan dan team work }\end{array}$ & $\begin{array}{l}0,663 \\
0,628 \\
0,701 \\
0,896 \\
0,872 \\
0,812 \\
0,656 \\
0,795 \\
0,795 \\
0,856 \\
0,617 \\
0,792 \\
\end{array}$ & 0,329 & $\begin{array}{l}\text { Valid } \\
\text { Valid } \\
\text { Valid } \\
\text { Valid } \\
\text { Valid } \\
\text { Valid } \\
\text { Valid } \\
\text { Valid } \\
\text { Valid } \\
\text { Valid } \\
\text { Valid } \\
\text { Valid }\end{array}$ \\
\hline
\end{tabular}

Sumber: Data Primer, 2020

\section{Uji Reliabilitas}

Reliabilitas perhitungan suatu kuesioner menggunakan SPSS dapat dilihat dari nilai Cronbach's Alpha, kemudian diinterpretasikan pada tabel skala Cronbach's Alpha(Sugiono, 2013).. Berikut tabel rangkuman hasil reliabilitas output SPSS:

Tabel.2. Hasil Realiabilitas

\begin{tabular}{lll}
\hline Variabel & $\begin{array}{l}\text { Cronbach's } \\
\text { Alpha }\end{array}$ & Keterangan \\
\hline $\begin{array}{l}\text { Gaya } \\
\text { Kepemimpinan }\end{array}$ & 0,941 & Reliabel \\
\hline $\begin{array}{l}\text { Kinerja } \\
\text { Pegawai }\end{array}$ & 0,932 & Reliabel \\
\hline
\end{tabular}

Sumber: Data Primer, 2020 


\section{Uji Koefisien Korelasi}

Setelah diketahui bahwa dalam instrumen ada beberapa yang valid dan dapat dipercaya, maka langkah selanjutnya adalah mencari arah dan kuatnya hubungan gaya kepemimpinan dengan kinerja pegawai dengan menggunakan rumus Korelasi. Karena data berupa interval maka digunakan korelasi Person Product Moment (Sugiono, 2013).

H0 : Tidak ada hubungan antara gaya kepemimpinan terhadap kinerja pegawai

H1 : Terdapat hubungan antara gaya kepemimpinan terhadap kinerja pegawai

Melalui bantuan program SPSS 16 maka hasil hubungan antara variabel gaya kepemimpinan terhadap kinerja pegawai dapat diihat pada tabel berikut ini:

Tabel.3. Hasil Koefisien Korelasi

\begin{tabular}{llrr}
\hline & & \multicolumn{2}{c}{ Gaya } \\
& & Kepemimpinan & \multicolumn{1}{c}{ Kinerja Karyawan } \\
\hline Pearson Correlation & Gaya Kepemimpinan & 1.000 & .385 \\
\cline { 2 - 4 } & Kinerja Karyawan & .385 & 1.000 \\
\hline Sig. (1-tailed) & Gaya Kepimpinan &. & .010 \\
\cline { 2 - 4 } & Kinerja Karyawan & .010 &. \\
\hline $\mathrm{N}$ & Gaya Kepemimpinan & 36 & 36 \\
& Kinerja Karyawan & 36 & 36 \\
\hline
\end{tabular}

Sumber: Data Primer, 2020

Berdasarkan tabel.3 maka dapat disimpulkan bahwa nilai korelasi (hubungan) antara gaya kepemimpinan dengan kinerja pegawai khususnya pada Bidang Perawatan pada PD Pasar Jaya HWI Lindeteves Jakarta Barat sebesar 0,385. Berdasarkan tabel pedoman interpretasi koefisien korelasi, nilai tersebut termasuk dalam kategori rendah yang memiliki hubungan sebesar 0,385. Melihat kedua variabel signifikan karena angka signifikansi sebesar 0,000 dengan demikian H1 diterima yang artinya terdapat hubungan rendah antara gaya kepemimpinan terhadap kinerja pegawai dimana dapat diartikan penerapan hubungan gaya kepemimpinan terhadap peningkatan kinerja karyawan masih tergolong rendah.

\section{Uji Koefisien Determinasi}

Hipotesis uji koefisien determinasi yang dihasilkan dalam penelitian ini adalah :

HO : Tidak ada pengaruh antara gaya kepemimpinan terhadap kinerja pegawai

H1 : Terdapat pengaruh antara gaya kepemimpinan terhadap kinerja pegawai

Dari hasil uji pengolahan data diperoleh data sebagai berikut:

Tabel 4.Model Summary

\begin{tabular}{|c|c|c|c|c|}
\hline Model & $\mathrm{R}$ & R Square & $\begin{array}{l}\text { Adjusted R } \\
\text { Square }\end{array}$ & $\begin{array}{l}\text { Std. Error of the } \\
\text { Estimate }\end{array}$ \\
\hline 1 & $.385^{\mathrm{a}}$ & .148 & .123 & 4.709 \\
\hline
\end{tabular}

a. Predictors: (Constant), Y

Terdapat tabel anova yang digunakan untuk menunjukkan besarnya angka signifikansi atau probabilitas dengan ketentuan angka probabilitas yang baik <0,05. Berikut ini adalah tabel anova:

Berdasarkan pada hasil tabel diatas menghasilkan tingkat signifikansi (angka probabilitas) sebesar 0,020 maka $\mathrm{H} 1$ diterima yaitu terdapat pengaruh antara gaya kepemimpinan terhadap kinerja pegawai.

Koefisien determinasi digunakan untuk mengetahui seberapa besar kemampuan variabel independen (gaya kepemimpinan) menjelaskan dependennya (kinerja pegawai) yang dilihat melalui $R$ Square dari perhitungan melalui program SPSS 16. Berikut ini adalah tabel hasil pengolahannya;

\section{Uji Persamaan Regresi}

Dalam uji persamaan regresi ini, hipotesa dapat dinyatakan

H0: Persamaan Regresi tidak signifikan

H1 : Persamaan Regresi signifikan 
Tabel 4. Hasil Analisis Regresi

Coefficients $^{\mathrm{a}}$

\begin{tabular}{|c|c|c|c|c|c|c|c|c|}
\hline \multirow{2}{*}{\multicolumn{2}{|c|}{ Model }} & \multicolumn{2}{|c|}{$\begin{array}{c}\text { Unstandardized } \\
\text { Coefficients }\end{array}$} & \multirow{2}{*}{$\begin{array}{c}\text { Standardized } \\
\text { Coefficients } \\
\text { Beta } \\
\end{array}$} & \multirow[b]{2}{*}{$\mathrm{t}$} & \multirow[b]{2}{*}{ Sig. } & \multicolumn{2}{|c|}{$\begin{array}{l}95.0 \% \text { Confidence } \\
\text { Interval for B }\end{array}$} \\
\hline & & $\mathrm{B}$ & $\begin{array}{l}\text { Std. } \\
\text { Error }\end{array}$ & & & & $\begin{array}{l}\text { Lower } \\
\text { Bound }\end{array}$ & $\begin{array}{l}\text { Upper } \\
\text { Bound }\end{array}$ \\
\hline & (Constant) & 33.435 & 8.286 & & 4.035 & .000 & 16.596 & 50.274 \\
\hline & $\begin{array}{l}\text { Kinerja } \\
\text { Karyawan }\end{array}$ & .360 & .148 & .385 & 2.433 & .020 & .059 & .661 \\
\hline
\end{tabular}

a.

Dependent Variable: Gaya kepemimpinan

Tabel 4. menggambarkan persamaan regresi untuk mengetahui uji hipotesis signifikansi koefisien regresi. Keputusannya adalah jika t hitung lebih kecil dari t tabel, maka H0 diterima, jika t hitung lebih besar dari t tabel, maka H1 ditolak. t hitung yang diperoleh dari tabel diatas adalah sebesar 2,433. Untuk menghitung t tabel, penulis menggunakan ketentuan sebagai berikut: a $=0,05$, Degree of Freedom $(\mathrm{DF})=$ (jumlah data -2 ) atau $36-2,5 \%=34,5 \%, \mathrm{t}$ tabel $=1,70$ (dilihat dari distribusi t tabel)karena $\mathrm{t}$ hitung $(2,433)$ lebih besar dari t tabel $(1,70)$, maka $\mathrm{H} 0$ ditolak dan $\mathrm{H} 1$ diterima yang artinya persamaan regresi signifikan dengan model persamaan linear

Regresi sederhana digunakan untuk melakukan prediksi seberapa tinggi nilai variabel dependen bila nilai variabel independen dimanipulasi (dirubah-rubah). Berdasarkan tabel III.24 didapat sigifikansi sebesar 0,020 maka H1 diterima yang artinya persamaan regresi signifikan sehingga berdasarkan tabel perhitungan SPSS diatas dapat diperoleh persamaan

$$
\mathrm{Y}=\alpha+\beta_{1} \mathrm{X}_{1}
$$

Sehingga menjadi persamaan sebagai berikut :

$$
\mathrm{Y}=33.435+0.360 \mathrm{X}_{1}
$$

Persamaan fungsi diatas, dapat diinterpretasikan bahwa bila gaya kepemimpinan bersifat konstan atau bernilai 0 (nol) maka Y (kinerja pegawai) adalah sebesar 33.435. koefisien regresi sebesar 0,360 menyatakan bahwa setiap penambahan satu satuan nilai gaya kepemimpinan akan meningkatkan kinerja pegawai sebesar 0,360. Sebaliknya jika gaya kepemimpinan mengalami penurunan satu satuan maka kinerja pegawai diprediksi mengalami penurunan sebesar 0,360. Dapat disimpulkan terdapatnya pengaruh dan hubungan antara gaya kepemimpinan dengan kinerja pegawai, semakin baik gaya kepemimpinan maka kinerja pegawai dapat meningkat.

\section{PENUTUP}

\section{Kesimpulan}

Berdasarkan hasil penelitian dan pembahasan mengenai Pengaruh Gaya Kepemimpinan Terhadap Kinerja Pegawai pada PD Pasar Jaya HWI Lindeteves Jakarta Barat, dapat disimpulkan sebagai berikut:

1. Berdasarkan hasil penelitian dengan menggunakan perhitungan Koefisien Korelasi Pearson Product Moment ini menunjukkan hasil sebesar 0,385. Berdasarkan pedoman interpretasi koefisien korelasi diperoleh tafsiran bahwa nilai tersebut berada dalam kategori rendah. Nilai tersebut menunjukkan adanya hubungan yang rendah antara gaya kepemimpinan terhadap kinerja pegawai.

2. Untuk mengetahui seberapa besar pengaruh gaya kepemimpinan terhadap kinerja pegawai dilakukan perhitungan Koefisien Determinasi (KD) yang menunjukkan nilai $R$ Square sebesar 0,148 sehingga dapat disimpulkan pengaruh gaya kepemimpinan terhadap kinerja pegawai sebesar $\mathbf{1 4 , 8 \%}$ sedangkan sisanya sebesar $\mathbf{8 5 , 2 \%}$ dipengaruhi oleh variabel lainnya seperti disiplin kerja, motivasi, pelatihan, kepuasan kerja, dan kompensasi.

3. Uji persamaan regresi juga dilakukan untuk membuat keputusan apakah naik turunnya variabel kinerja pegawai dapat dilakukan melalui peningkatan variabel gaya kepemimpinan dan berdasarkan perhitungan uji persamaan regresi tersebut diketahui bahwa $\mathrm{H} 1$ diterima dan $\mathrm{H} 0$ ditolak yaitu persamaan regresi 
signifikan dan diperoleh persamaan regresi yaitu $\mathbf{Y}=\mathbf{3 3 , 4 3 5}+\mathbf{0 , 3 6 0} \mathrm{X}$. dari persamaan regresi tersebut dapat dianalisa bahwa: pertama, apabila tidak ada gaya kepemimpinan maka kinerja pegawai sebesar $\mathbf{3 3 , 4 3 5}$. Kedua, apabila gaya kepemimpinan ditambah 1 satuan maka akan menambah kinerja pegawai sebesar 0,360 satuan dimana dapat diartikan semakin meningkat dan efektif gaya kepemimpinan maka dapat meningkatkan kinerja karyawan

\section{Saran}

Berdasarkan pembahasan dalam penelitian ini, maka penulis memberikan saran sebagai berikut:

1. Kondisi perusahaan instansi yang nyaman bagi pegawai tentu akan berdampak pada perilaku dan kinerja pegawai dalam melaksanakan pekerjaannya. Untuk itu kepala bidang perawatan sebaiknya terus berupaya memperbaiki dan memelihara budaya dan iklim organisasi yang kondusif dengan berupaya untuk lebih memahami penerapan gaya kepemimpinan yang sesuai dengan berbagai kondisi yang sedang dihadapi.

2. Sebaiknya kepala bidang perawatan dapat terus menciptakan suasana yang lebih akrab dan meningkatkan komunikasi yang lebih intensif kepada pegawai. Komunikasi tersebut dapat dikemas dalam suasana santai yang akrab namun diisi dengan motivasi-motivasi ataupun saran-saran tentang perbaikan kinerja pegawai.

\section{DAFTAR PUSTAKA}

Anwar, Ruyatnasih. (2013). Pengaruh Gaya Kepemimpinan Terhadap Kinerja Karyawan pada Bagian Operator SPBU PT.Mitrabuana Jayalestari Karawang. Jurnal Managemen, Vol.10, No.3.

Bangun, Wilson.(2012).Managemen Sumber Daya Manusia. Jakarta: Erlangga

Fahmi, Irham. (2013).Manajemen Kepemimpinan Teori dan Aplikasi. Bandung: Alfabeta.

Hao, Moo Jun dan Yazdanifard.(2015) How Effective Leadership can Facilitate Change in Organizations through Improvement and Innovation. Volume 15 Issue 9

Kartono, Kartini. (2010). Pemimpin dan Kepemimpinan. Jakarta: Rajawali Pers

Rivai, Veithzal, dan Deddy Mulyadi. 2011.Kepemimpinan dan Perilaku Organisasi. Edisi Pertama. PT Raja Grafindo Persada - Jakarta

Soekarso, Agus Sosro, Iskandar Putong, dan Cecep Hidayat. 2010. Teori Kepemimpinan. Jakarta: Mitra Wacana Media

Sugiyono. (2013). Metode Penelitian Administrasi (Dilengkapi dengan Metode R\&D). Alfabeta - Bandung

Sutrisno, H. Edy. (2013). Budaya Organisaisi. Kencana - Jakarta.

Tampi, Bryan Johannes. (2014). Pengaruh Gaya Kepemimpinan dan Motivasi Terhadap Kinerja Karyawan pada PT.Bank Negara Indonesia, Tbk (Regional Sales Manado). Jurnal Acta Diurna, Vol.3, No.4

T.S, Nanjundeswaras wamy dan D.R Swami.(2014).Leadership Styles.Advances in Management.Vol.7(2) February(2014).57 -62

Visser, Victoria. (2013). Leader Affect and Leadership Effectiveness How Leader Affective Displays Influence Follower Outcomes. Rotterdam : Erasmus Universiteit Rotterdam 